\title{
The Romanian Judicial Professions Database: An Open-Source Tool for Researching the Romanian Legal System
}

\author{
Radu Andrei Pârvulescu
}

September 14, 2020*

\begin{abstract}
Justice is a perennial topic in scholarship on Romania, from socialist legality, through transitional justice, and into anti-corruption. Systematic study of law and justice has been stymied, however, by lack of basic information: who was doing what, where, when and how? To begin addressing this shortcoming this article introduces the Romanian Judicial Professions Database, a new, open-source tool which provides yearly, person-level data on 10,000 judges, 5300 prosecutors, 3000 notaries public (notari publici), and 1000 bailiffs (executori judecătoreşti), in some cases going back to the 1970s. To illustrate the utility of these new data, I derive a series of measures which address existing findings as well as open questions in four areas of research: the communist legal system, transitional justice, anti-corruption, and social stratification. The database can be downloaded at https://osf.io/gfjke/ and supporting code at https://github.com/r-parvulescu/ro judicial professions.
\end{abstract}

keywords: professions, law, justice, Romania, database, open source

“Astăzi, avem acces la monografii despre orașe și sate, despre instituții cu importanță limitată, dar despre justiție încă nu." - Iuliu Crăcană, Dreptul în slujba puterii ${ }^{1}$

\section{Introduction}

Law and justice are arguably the most studied elements of contemporary Romania, often involving personnel issues. Did Ceauşescu-era magistrates ${ }^{2}$ dominate transitional justice? How many judges retired early due to incessant fights over anti-corruption? Are all notaries public (notari publici) someone's daughter, nephew, or godchild? Such questions have been difficult to answer because data on Romanian legal professionals are secret, scattered, or both. This article introduces the Romanian

*Radu Andrei Pârvulescu is a doctoral candidate in the Department of Sociology at Cornell University, and a visiting scholar in the Department of Sociology, Anthropology, and Social Work at the University of Dayton. Address correspondence to Radu Andrei Pârvulescu, Department of Sociology, Uris Hall, 109 Tower Road, Ithaca, NY, 14850, USA; email: rap348@cornell.edu.

1 "These days we have histories of towns and villages and monographs on institutions of limited importance, but nothing yet on justice and the laws.” Crăcană (2015:20)

2 In Romania, as in France, judges and prosecutors share the legal status of "magistrate.” 
Legal Professions Database, a new, open-source directory with yearly, person-level data on 10,000 judges, 5300 prosecutors, 3000 notaries public (notari publici), and 1000 bailiffs (executori judecătoreşti). These new data allow us to investigate, over many years and in great detail, aspects of the Romanian legal system which have puzzled but eluded previous researchers.

The first section pulls out key expectations and questions from Romania-focused research on four topics: the communist justice system, transitional justice, anti-corruption, and social stratification. These efforts justify the need for more and better data. The second section provides a non-technical introduction the Romanian Legal Professions Database, describing the digitised archives on which the database is built, and highlighting key elements of the software which collects, processes, and integrates said archives. This database is free and open-source: anyone can download, use, and improve it. The third portion of this article illustrates how the Romanian Judicial Professions Database can address the expectations and questions distilled in the first section. My aim is to communicate the exciting avenues opened up by this new and freely available data, which can be leveraged by any student of contemporary Romania. I conclude with comments on the limitations of this database and suggestions for future research.

\section{Expectations and Question from Four Subfields}

In this section I pull out empirical expectations and open questions from research tackling the communist legal system, transitional justice, anti-corruption, and social stratification. The aim is to underscore existing findings against which new data should be measured, and to highlight unsolved problems in need of study.

\section{a. The Communist Legal System}

Critical research on communist Romania is still in its infancy, and is focused primarily on the imposition of Stalinism (Kligman and Verdery 2011; Tismaneanu 2003). Regarding the legal system, Iuliu Crăcană’s (2015) study of the sovietisation of Romanian justice between 1945 and 1958 remains the gold standard. That author notes that nearly all archives of the Ministry of Justice from 1945 to 1989 remain inaccessible; working with what he could gather, Crăcană only covered 1945-1958 (2015:20$27,33)$. In other words, rigorous historiography of communist justice ends in 1958 . We know practically nothing about the effects on the Romanian legal system of the reintroduction of counties in 1968 , the 1978 overhaul of the legal code(s), or really any Ceauşescu-era reforms.

We can expect, however, that "socialist legality" was established by 1958, and therefore that the legal system was stable until 1990. But was this dynamic stability, or ossification?

\section{b. Transitional Justice}

Researchers of Romania's post-socialist "transition" and popular wisdom both agree that only top-tier communists were sacked in 1989, while the next level kept their jobs and often thrived, in the security services (Stan and Zulean 2018), electoral politics (Protsyk and Matichescu 2011) or business (Stoica 
2004). As for the legal system, one need only mention Minister of Justice Rodica Stănoiu (2000-2003), an erstwhile secret police informer who promoted her former Securitate supervising officer to head the ministry's judicial spying office. ${ }^{3}$

Another area of research has focused on property restitution, simultaneously an act of restitutive justice for communist-era confiscations, a leading wedge issue in electoral politics, and a frenzy of primitive accumulation (Dorondel 2016). Property restitution was arguably the baptism by fire of postsocialist Romanian law, as this policy saw then-president Iliescu order judges to ignore the law, led to a highly symbolic ruling from the European Court of Human Rights contradicting national legal practice, and jump-started real estate markets by giving large swathes of the population property that they could sell.

One expectation is therefore that the transition witnessed stability of magistrate cadres. The question tackles the effects of property re-commodification: was restitution a foundational policy for post-socialist legal professions, by increasing the demand for property-related legal services?

\section{c. Anti-corruption}

Anti-corruption has been the wedge of Romanian politics since 2004. While disagreement continues as to its partiality and ultimate usefulness, there is an emerging consensus that anti-corruption sustains populist politics, as politicians of every colour can always score points by attacking "the establishment,” however defined (Dragoman 2020; Gherghina and Soare 2017). This has led to numerous attempts to reform the justice system, most recently during 2017-2019 by the PSD-ALDEUDMR parliamentary coalition. Anti-corruption has certainly grabbed headlines, and sometimes even system-level problems have been covered in the press. ${ }^{4}$ But long-term shifts in the judicial system have not made it into either the news cycle, or academic debate.

From anti-corruption research we can therefore expect that populist reforms have affected the magistracy,while the deeper question addresses the extent to which the very architecture of the legal system has been altered by the anti-corruption drives.

\section{d. Social Stratification}

Research has shown that Romanians have different expectations of men and women (Voicu and Tufiş 2012), including in the workplace (Curseu and Boros 2008). Some of these views have changed with surprising speed, in part because of the rapidly shifting nature of Romania's economy (Voicu and Tufiş 2012:72-74). We also know that returns to education (i.e. the extent to which a person's wage depends on their total years of schooling) in Romania have increased significantly since the end of socialism, as schooling has become more valuable (Andrén, Earle, and Săpătoru 2005). Nevertheless, clear findings about class production and reproduction remain elusive (Tomescu-Dubrow 2006). Consequently, we expect significant changes in the status and prestige of women, and enquire into the quality and mechanisms of intergenerational mobility. Table 1 summarises the expectations and questions from the

3 Mihăescu (2018)

4 Digi24 (2019) 
four topics reviewed above.

\begin{tabular}{|c|c|c|}
\hline Topic & Expectation & Question \\
\hline Communist Law & Stable system in late communism. & Stable but dynamic system, or ossified? \\
\hline Transitional Justice & $\begin{array}{c}\text { Stability of magistrate cadres during } \\
\text { the transition. }\end{array}$ & $\begin{array}{c}\text { Did property restitution significantly } \\
\text { affect judicial professions? }\end{array}$ \\
\hline Anti-corruption & $\begin{array}{c}\text { Anti-corruption politics affects } \\
\text { judicial careers. }\end{array}$ & $\begin{array}{c}\text { Was legal architecture altered by anti- } \\
\text { corruption policies? }\end{array}$ \\
\hline Stratification & $\begin{array}{c}\text { Changing occupational status of } \\
\text { women. }\end{array}$ & $\begin{array}{c}\text { What causes varying rates of } \\
\text { intergenerational mobility? }\end{array}$ \\
\hline
\end{tabular}

Table 1: Expectations and questions from four strands of research on Romania.

\section{Introducing the Romanian Legal Professions Database}

The Romanian Legal Professions Database is a package of digitised archives and the computer code which processes them. The offspring of this archive-code combination are a series of person-year tables, one for each different legal profession (plus law school graduates), where each row refers to one person in one year, and lists their attributes. Tables 2 and 3 exemplify one judge and one notary personyear. The attributes vary by professions: for example, only prosecutors and judges have hierarchical levels (from municipal low court to national high court), while only bailiffs feature office addresses. Appendix A lists the attributes/variables of each person-year table.

\begin{tabular}{|l|l|l|l|l|l|l|l|l|l|l|}
\hline $\begin{array}{l}\text { Row } \\
\text { ID }\end{array}$ & $\begin{array}{l}\text { Pers. } \\
\text { ID }\end{array}$ & Surname & $\begin{array}{l}\text { Given } \\
\text { Name }\end{array}$ & Sex & Workplace & Year & $\begin{array}{l}\text { Appeals } \\
\text { Code }\end{array}$ & $\begin{array}{l}\text { Tribunal } \\
\text { Code }\end{array}$ & $\begin{array}{l}\text { Low Court } \\
\text { Code }\end{array}$ & Level \\
\hline 24482 & 2291 & Corbu & $\begin{array}{l}\text { Corina } \\
\text { Alina }\end{array}$ & F & $\begin{array}{l}\text { Tribunalul } \\
\text { Bucureşti }\end{array}$ & 2006 & CA4 & TB9 & -88 & 2 \\
\hline
\end{tabular}

Table 2: Example of person-year entry from the judges data table

\begin{tabular}{|l|l|l|l|l|l|l|l|}
\hline RowID & PersID & Surnames & $\begin{array}{l}\text { Given } \\
\text { Names }\end{array}$ & Sex & Year & Chamber & Town \\
\hline 43680 & 2921 & Toader & Tudorel & $\mathrm{M}$ & 2018 & Iaşi & Iaşi \\
\hline
\end{tabular}

Table 3: Example of person-year entry from the notaries public data table

As of this writing the database covers four professions - judges, prosecutors, notaries public (notari publici) and bailiffs (executori judecătoreşti) - and one extra-professional group (law school graduates), over periods ranging from fifteen to forty years; see Table 4 for details. 


\begin{tabular}{|l|l|l|}
\hline Profession/Group & Years Available & Notes \\
\hline Judges & $1978-2020$ & $\begin{array}{l}\text { Complete population after 2005, sample before; person- } \\
\text { level data with full name }\end{array}$ \\
\hline Prosecutors & $1988-2020$ & $\begin{array}{l}\text { Complete population after 2005, sample before; person- } \\
\text { level data with full name }\end{array}$ \\
\hline $\begin{array}{l}\text { Notaries Public } \\
\text { (notari publici) }\end{array}$ & $1995-2019$ & $\begin{array}{l}\text { Complete population after 2005, sample before; person- } \\
\text { level data with full name }\end{array}$ \\
\hline $\begin{array}{l}\text { Bailiffs (executori } \\
\text { judecătoreşti) }\end{array}$ & $2001,2003-2019$ & $\begin{array}{l}\text { Complete population after 2005, sample before; person- } \\
\text { level data with full name }\end{array}$ \\
\hline $\begin{array}{l}\text { Law School } \\
\text { Graduates }\end{array}$ & $1974-2019$ & $\begin{array}{l}\text { Person-level, anonymised data for Iaşi law school } \\
\text { graduates, 1986-2019; aggregate data for Cluj graduates, } \\
\text { 1974-2019 }\end{array}$ \\
\hline
\end{tabular}

Table 4: Data availability and details for four judicial professions and one extra-judicial group (law school graduates)

The digitised archives are routinely updated with new information: for example, the Superior Council of the Magistracy (the joint professional body of judges and prosecutors) releases monthly employment rolls for all courts and prosecutors" offices (also known as "parquets") in Romania. We can therefore study the unfolding of current events, such as the COVID-19 crisis. ${ }^{5}$ Archival collection and digitisation is also ongoing with respect to historical data (e.g. prosecutors before 1988) and other legal professions (e.g. lawyers).

The archival material (usually professional employment/membership rolls) was obtained through freedom of information requests (per law 544/2001), requests to non-public entities (e.g. the National Union of Notaries Public of Romania), or by accessing publicly available data on the website of the Superior Council of the Magistracy (the CSM) or the National Union of Bailiffs. In a few cases I was granted access to the physical archives of Romanian courts and parquets. These raw data are also freely available in the online package, with the exception of student names and photographs of court archives, as these are strictly regulated by European data privacy laws (GDPR). The digitised archives as well as the output tables can be downloaded at https://osf.io/gfjke/.

These sources contain a tremendous amount of information: since 2005 alone we have monthly observations for nearly four hundred courts and parquets, covering some five thousand judges and half as many prosecutors. One must therefore automate data collection, processing, and integration. This is achieved using an original software package written in Python, which isolates person years, cleans attribute information (e.g. standardising diacritics), and generates person-year tables; this package is freely available at https://github.com/r-parvulescu/ro judicial professions.

While most tasks handled by this software package are routine (e.g. splicing data from different files, assigning each geographic area a unique identifier) two coding elements are worth mentioning, as these often come up in "big data" research. First, I automatically assign sex/gender by running given

5 See for example Pârvulescu (2020a) 
names through a purpose-built dictionary which assigns a gender to each name (e.g. Radu: M, Monica: F). In the rare case that given names do not agree (e.g. Ionel Elena) I assign a value of “don't know.”

Second, the software identifies unique persons by standardising full names, then grouping observations with the same full name. Table 5 illustrates both the name-diversity problem and its solution: while a computer would normally treat the raw names as referring to six different people, the name standardiser applies the human intuition that we are actually dealing with one person who has suffered name changes, due to both inconsistent book-keeping and marriage. Other tools ensure that people with identical names (often common ones like "Cristina Popescu”) are not spuriously combined. A full description of the package and its capabilities can be found in the documentation on the previously-mentioned GitHub site.

\begin{tabular}{|l|l|l|}
\hline Year & Raw Name & Standardised Name \\
\hline 2007 & Marcela Sandu & Marcela Viorica Popescu Sandu \\
\hline 2008 & Marcela Sandu & Marcela Viorica Popescu Sandu \\
\hline 2009 & Marcela Viorica Sandu & Marcela Viorica Popescu Sandu \\
\hline 2010 & Marcela Viorica Sandu-Popescu & Marcela Viorica Popescu Sandu \\
\hline 2011 & Marcela Sandu-Popescu & Marcela Viorica Popescu Sandu \\
\hline 2012 & Marcela Sandu-Popescu & Marcela Viorica Popescu Sandu \\
\hline 2013 & Marcela Popescu & Marcela Viorica Popescu Sandu \\
\hline 2014 & Marcela Viorica Popescu & Marcela Viorica Popescu Sandu \\
\hline 2015 & Marcela Viorica Popescu & Marcela Viorica Popescu Sandu \\
\hline
\end{tabular}

Table 5: Illustration of name transformation by the name standardising function

I close this section by highlighting three benefits of online, open-source databases under permissive intellectual property licenses (in this case Creative Commons NC-ND 4.0). First, anyone can take the data and use it as they see fit, no permission required: all they must do is cite this article. Second, since the software package is a GitHub project any research team with programming experience can "pull” the project from the online repository, make improvements, and "push" it back. In this way the database can continue evolving well beyond its original scope. Finally, because the data and code are publicly available, all results are reproducible, which encourages open science.

\section{Applying the Romanian Judicial Professions Database}

It is time to see what these data can do, by applying them to the expectations and questions from Section 2. My immediate goal is not to provide rigorous tests, but to highlight the range of topics which can be tackled by the Romanian Judicial Professions Database. With the exception of the network graphs (which use a third-party program) all results are obtained from the software package's "Describe" module, which generates the descriptive statistics reported below. 


\section{a. The Communist Judiciary}

Regarding the communist legal system, we expect system stability after 1958, and ask whether the system was ossified or featured change, within the boundaries of socialist law. Table 6 shows the number of judges in low courts and county tribunals, as well as the rate of promotion between these two levels, from 1978 to $1988 .^{6}$

\begin{tabular}{|l|l|l|l|l|}
\hline Year $\downarrow$ & $\begin{array}{l}\text { Total (Low Court }+ \\
\text { Tribunal }\end{array}$ & $\begin{array}{l}\text { Count Low } \\
\text { Court }\end{array}$ & $\begin{array}{l}\text { Total Promoted from } \\
\text { Low Court to Tribunal }\end{array}$ & Percent Promoted \\
\hline 1978 & 546 & 365 & 3 & 0.82 \\
\hline 1979 & 552 & 368 & 8 & 2.17 \\
\hline 1980 & 564 & 377 & 13 & 3.45 \\
\hline 1981 & 564 & 376 & 6 & 1.6 \\
\hline 1982 & 566 & 384 & 3 & 0.78 \\
\hline 1983 & 563 & 381 & 5 & 1.31 \\
\hline 1984 & 558 & 377 & 15 & 3.98 \\
\hline 1985 & 570 & 379 & 32 & 8.44 \\
\hline 1986 & 586 & 377 & 10 & 2.65 \\
\hline 1987 & 592 & 381 & 16 & 4.2 \\
\hline 1988 & 544 & 354 & 5 & 1.41 \\
\hline Average & $\underline{564}$ & $\underline{374}$ & $\underline{11}$ & $\underline{2.8}$ \\
\hline
\end{tabular}

Table 6: Yearly Sample Count of Total Judges, Total Low Court Judges, Total Low Court Judges Promoted to County Tribunal, and Percent Rate of Promotion, 1978-1988

We see that the communist judiciary was indeed stable between 1978 and 1988. Despite yearly fluctuations the profession did not grow over in this period, and the yearly promotion rate ended the decade where it began, despite a boost in 1984-1985. Table 7, however, shows an important source of change: over 1978-1988 the socialist judiciary was feminising. This should not be entirely surprising: during this period law schools ${ }^{7}$ began graduating more women. On the surface and at least within the judiciary, the usually unfulfilled communist promise of workplace equality between men and women

6 These data refer to judges serving in a sample courts located in 20 counties, at low court and tribunal level - there were no courts of appeals during socialism. Given the centralisation of judicial management in the ministry of justice, I argue that the trends from this sample are representative of the entire Romanian judicial system from 1978 to 1988 . The sampled counties are: Alba, Hunedoara, Sibiu, Neamţ, Covasna, Călăraşi, Ialomiţa, Teleorman, Bistriţa-Năsăud, Maramureş, Tulcea, Gorj, Mehedinţi, Iaşi, Argeş, Buzău, Dâmboviţa, Prahova, Arad, Caraş-Severin, Harghita, Mureş,

7 These data are only of graduating cohorts from the Cluj law school: I have no reason to believe that these figures were different for the Iaşi and Bucharest law schools, the only other ones in Romania at that time. 
was becoming reality. We therefore tentatively conclude that, with regard to the communist judiciary, 1978 to 1988 represented stability, not ossification.

\begin{tabular}{|l|l|l|l|l|l|l|l|l|l|l|l|}
\hline Year $\rightarrow$ & $\mathbf{1 9 7 8}$ & $\mathbf{1 9 7 9}$ & $\mathbf{1 9 8 0}$ & $\mathbf{1 9 8 1}$ & $\mathbf{1 9 8 2}$ & $\mathbf{1 9 8 3}$ & $\mathbf{1 9 8 4}$ & $\mathbf{1 9 8 5}$ & $\mathbf{1 9 8 6}$ & $\mathbf{1 9 8 7}$ & $\mathbf{1 9 8 8}$ \\
\hline Total & 546 & 552 & 564 & 564 & 566 & 563 & 558 & 570 & 586 & 592 & 544 \\
\hline \% female & 28 & 27 & 28 & 28 & 30 & 32 & 32 & 32 & 34 & 35 & 37 \\
\hline $\begin{array}{l}\text { \% female Cluj } \\
\text { law grads }\end{array}$ & 58 & 51 & 58 & 57 & 59 & 58 & 55 & 54 & 59 & 61 & 66 \\
\hline
\end{tabular}

Table 7: Yearly Sample Count of Total Judges and Percent Female of Total, 1978-1988

\section{b. Magistrates in Transition}

The transition literature suggests that Ceauşescu-era judges and prosecutors kept their jobs in the 1990s, while putative links between legal professions and land privatisation present open questions. Table 8 shows county-level departure rates ${ }^{8}$ for judges and prosecutors at different levels of the judicial hierarchy, from 1988 to $1992 .{ }^{9}$ These samples account for roughly a third of all magistrates, in a representative set of counties. ${ }^{10}$ The 1989 revolution slightly increased retirements for low court judges and thoroughly overhauled the High Court: tribunal judges and prosecutors were unaffected. This broadly agrees with the transition literature: minimal turnover except among first ranked communists.

As to land privatisation and legal work, we look at the judicial profession most associated with property, notaries public (notari publici), whose signature is required whenever property changes hands. The size of this professional group is not a perfect proxy for growth in the property market, because notaries also handled other legal tasks in demand after 1989, such as certifying noncontentious divorce. Still, the real money was and is in conveyance, i.e. property transfers. ${ }^{11}$ Table 9

8 This metric captures how many people leave the sample each year, i.e. can no longer be located in any of the parquets located in the sampled counties. Strictly speaking, this measure conflates actual departure from the profession with transfer to units not in the sample. However, estimates of inter-unit mobility suggest that such transfers were very rare in this period, with most careers evolving in one county: in 1991 we only observe eight within-sample, inter-area movements for judges (out of 1116 sample judges), and five such movements for prosecutors (out of a sample of 389). Consequently, I claim that this measure does adequately reflect actual departures from the profession, due to retirement or death.

9 I selected 1988-1992 in order to focus on the revolutionary period, and because the re-introduction of the appellate level in 1993 radically altered career dynamics, by opening a previously-unavailable, higher step of pay and prestige for career magistrates. The High Court (before 1990 known as Tribunalul Suprem, and from 1990 to 2003 as Curtea Supremă de Justiţie) and General Parquet in Bucharest had always been too small to be a realistic career goal for most magistrates. The database does not yet contain pre-2005 data on the General Procuracy (Parchetul General, later Parchetul de pe lângă Înalta Curtea de Casaţie şi Justiţie).

10 The sampled counties are: Bacău, Neamţ, Covasna, Călăraşi, Giurgiu, Ialomiţa, Bistriţa-Năsăud, Maramureş, Sălaj, Mehedinţi, Olt, Sibiu, Vaslui, Satu Mare, Vâlcea, Buzău, Dâmboviţa, Harghita.

11 Using the number of notaries to index property market activity is defensible for three additional reasons. First, the actual act of restitution did not involve notaries, as this was an administrative action of the state, so restitution itself did not inflate the profession. Second, the slew of court cases involving questionable restitutions also did not benefit the notaries, since this profession deals strictly with non-contentious civil law and cannot by law represent anyone in court; the main beneficiaries 
shows the size of the population of notaries in Romania between 1995 and 2005, the interval in which most property restitution took place.

\begin{tabular}{|c|c|c|c|c|c|c|c|c|c|c|}
\hline \multirow[b]{3}{*}{ Level $\downarrow /$ Year $\rightarrow$} & \multicolumn{10}{|c|}{ Departure Counts (percent of sample) } \\
\hline & \multicolumn{5}{|c|}{ Judges } & \multicolumn{5}{|c|}{ Prosecutors } \\
\hline & 1988 & 1989 & 1990 & 1991 & 1992 & 1988 & 1989 & 1990 & 1991 & 1992 \\
\hline $\begin{array}{l}\text { Low Court } \\
\text { (\% of total) }\end{array}$ & $\begin{array}{l}14 \\
(3 \%)\end{array}$ & $\begin{array}{l}24 \\
(4 \%)\end{array}$ & $\begin{array}{l}45 \\
(8 \%)\end{array}$ & $\begin{array}{l}35 \\
(5 \%)\end{array}$ & $\begin{array}{l}50 \\
(7 \%)\end{array}$ & $\begin{array}{l}18 \\
(8 \%)\end{array}$ & $\begin{array}{l}17 \\
(7 \%)\end{array}$ & $\begin{array}{l}23 \\
(10 \%)\end{array}$ & $\begin{array}{l}17 \\
(7 \%)\end{array}$ & $\begin{array}{l}24 \\
(10 \%)\end{array}$ \\
\hline $\begin{array}{l}\text { County Tribunal } \\
\text { (\% of total) }\end{array}$ & $9(3 \%)$ & \begin{tabular}{|l|}
29 \\
$(9 \%)$
\end{tabular} & \begin{tabular}{|l}
33 \\
$(9 \%)$
\end{tabular} & $\begin{array}{l}13 \\
(4 \%)\end{array}$ & \begin{tabular}{|l}
31 \\
$(8 \%)$
\end{tabular} & $5(7 \%)$ & $\begin{array}{l}6 \\
(10 \%)\end{array}$ & $\begin{array}{l}7 \\
(11 \%)\end{array}$ & $3(5 \%)$ & $\begin{array}{l}12 \\
(18 \%)\end{array}$ \\
\hline $\begin{array}{l}\text { High Court } \\
\text { (\% of total) }\end{array}$ & $0(0 \%)$ & $\begin{array}{l}19 \\
(70 \%)\end{array}$ & $0(0 \%)$ & $2(5 \%)$ & $2(5 \%)$ & & & NA & & \\
\hline
\end{tabular}

Table 8: Yearly sample count and percent of departures/retirements of judges and prosecutors by level in judicial hierarchy, 1988-1992

\begin{tabular}{|l|l|l|l|l|l|l|l|l|l|l|l|}
\hline Year $\rightarrow$ & $\mathbf{1 9 9 5}$ & $\mathbf{1 9 9 6}$ & $\mathbf{1 9 9 7}$ & $\mathbf{1 9 9 8}$ & $\mathbf{1 9 9 9}$ & $\mathbf{2 0 0 0}$ & $\mathbf{2 0 0 1}$ & $\mathbf{2 0 0 2}$ & $\mathbf{2 0 0 3}$ & $\mathbf{2 0 0 4}$ & $\mathbf{2 0 0 5}$ \\
\hline Total Count & 486 & 722 & 736 & 830 & 931 & 1087 & 1179 & 1233 & 1335 & 1447 & 1442 \\
\hline $\begin{array}{l}\text { Yearly } \% \\
\text { Increase }\end{array}$ & & $49 \%$ & $2 \%$ & $13 \%$ & $12 \%$ & $17 \%$ & $9 \%$ & $5 \%$ & $8 \%$ & $8 \%$ & $0 \%$ \\
\hline
\end{tabular}

Table 9: Yearly population count and year-on-year percent increase of notaries public (notari publici), 1995-2005

The number of notaries tripled between 1995 and 2005, with the biggest percent increase immediately after their privatisation in 1995, suggesting that the re-commodification of property directly contributed to the expansion of this important and ubiquitous professional group. Summing up, we do observe the expected stability of magistrate cadres, and land privatisation does seem to have significantly impacted the Romanian legal system via the breakneck expansion of a key legal profession, the notaries public.

\section{c. Anti-corruption and Professional Mobility}

Anti-corruption research and casual political observation would expect political reactions to judicialised anti-corruption to systematically affect magistrate careers. It is an open question whether the architecture of the legal system has been significantly impacted. Figure 1 presents the yearly retirement rate of appeal-level magistrates, ${ }^{12}$ the higher echelon of judges and prosecutors from which

of these lawsuits were probably lawyers. Finally, as discussed below with regards to Figure 4, the most intense, postprivatisation recruitment of notaries public took place between 2006 and 2011, when the Romanian property market experienced a bubble and consequently high demand for conveyancing.

12 Unlike the similar metric mentioned in footnote 3 above, this measure strictly captures retirements, because after 2005 we have data on the entire population of judges and prosecutors. 
for the national judicial leadership is recruited.

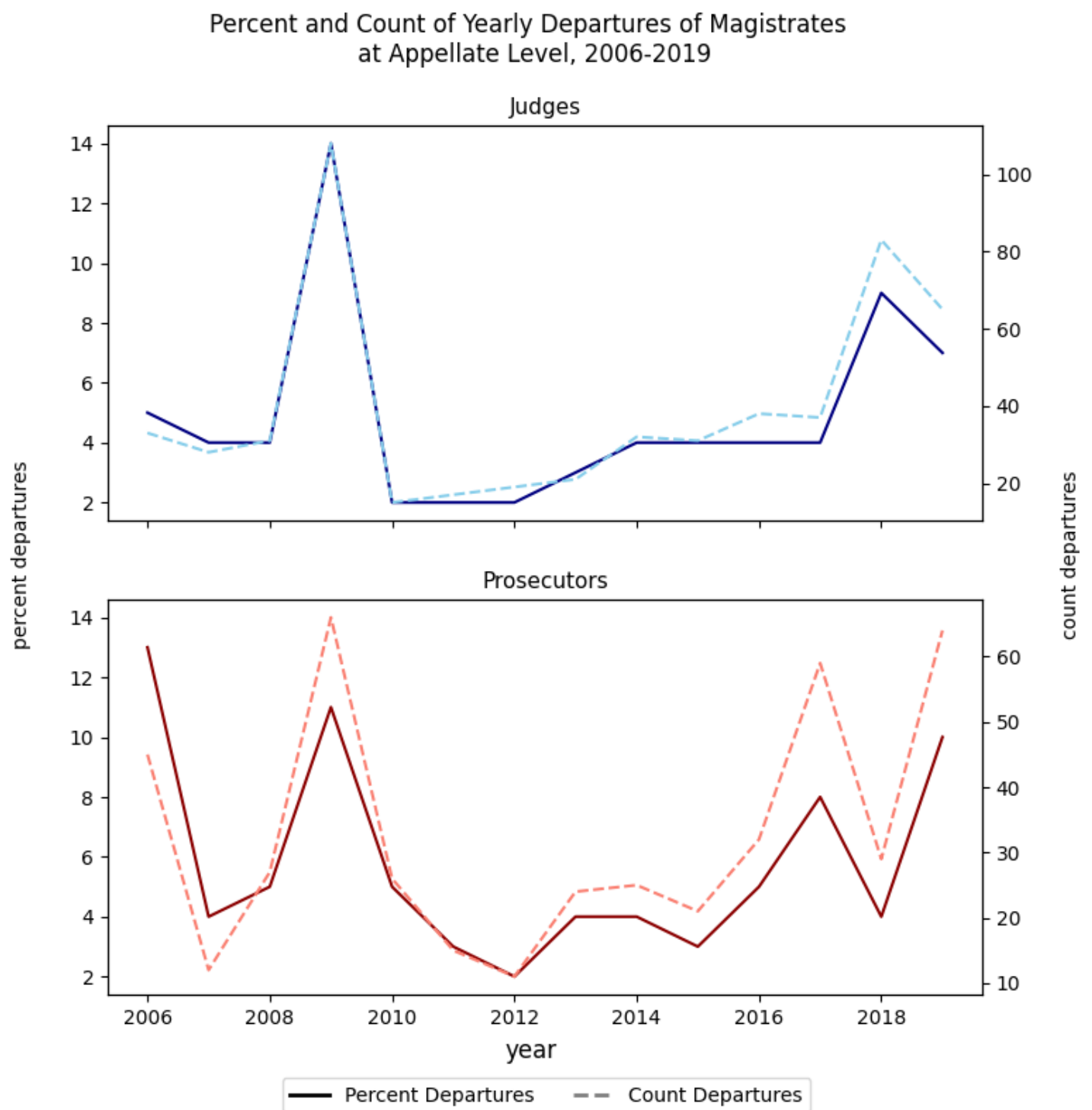

Figure 1: Yearly population count and percent of departures/retirements of judges and prosecutors at the appellate level, 2006-2019

First, this figure suggests that the incomplete legal system reforms of 2017-2019 (which were sold as "anti-anti-corruption" policies) did increase the retirement rate of appellate -level magistrates, though I am surprised by the lack of effects in other years, e.g. 2006-2008. The spike in 2009 is problematic. It could reflect the scheduled but belatedly implemented reform of criminal and civil law, as senior magistrates may have retired in anticipation of their legal knowledge becoming obsolete. Increased retirement may also have been an early reaction to the global financial crisis. ${ }^{13}$ Finally, these measures could be artefactual, since the CSM changed its reporting format that year, causing a messy data transition. I mention these to underscore both interpretative plurality and the fact that this database is a work in progress, with an open-source invitation to interested parties.

13 The implications of this scenario were discussed in a recent op-ed Pârvulescu (2020b). 
To explore the possible impact of anti-corruption policies on the architecture of the legal system, Figures 2 and 3 present the 2013-14 network of transfers between appellate regions, separately for judges and prosecutors. Nodes represents the courts/parquets in one appellate region (e.g. Craiova, which includes Dolj, Gorj, Mehedinţi and Olt counties), while connecting lines signify personnel flows: for instance, how many judges transferred between the Craiova and Bucharest appellate regions in 2013. ${ }^{14}$ The High Court and its Parquet are coded independently, as are the specialised prosecutor agencies - DNA (the National Anti-corruption Directorate) and the DIICOT (the Directorate for the Investigation of Organised Crime and Terrorism) - because each agency has its own territorial structure and internal hierarchy and employs as many prosecutors as a larger appellate region.

These graphs reveal how the specialised agencies, the DNA and the DIICOT, anchor and divide the prosecutor network, imposing a non-geographic organising principle on the procuracy and consequently a distinct career typology: one can be a DNA, DIICOT, or "regular" prosecutor. ${ }^{15}$ Similarly-coloured nodes indicate "cliques," groups of appellate areas tightly connected by personnel flows. This shows that each specialised agency has a turf with which it preferentially exchanges prosecutors. Compare this to the judge network: without special agencies, the judicial network is strictly territorial, with two cliques anchored by the Bucharest and Cluj regions, and another of stragglers. The judicial network suggests what the prosecutor network would be like without the DNA and the DIICOT. To sum, the magistracy seems to have been somewhat affected by political reactions to Romania's judicialised anti-corruption drive, and the presence of the specialised anti-corruption agency (the DNA) does noticeably affect the architecture of the procuracy.

\section{d. Stereotype Change and Professional Inheritance}

Research on both Romania (Voicu and Tufiş 2012) and the USA (Ridgeway 2011) suggests that occupational stereotypes associating men and women with different tasks and general levels of competence change along with the distribution of visible social power: as more women are seen in positions of influence people are more likely to associate women with competence and authority. Figure 4 shows that despite differences in the representation of women across four legal professions, all groups have feminised significantly since 1989. The most powerful and visible of them all, the judiciary, has actually become dominated by women. To appreciate the symbolism one need only consult court photos of the most powerful man in the country (former party-leader Liviu Dragnea) being sent to a jail by a panel of five women judges.

14 In the jargon of network analysis, these are weighted, directed edges (the arrows have been suppressed for visual simplicity). I measure centrality via shortest-path betweenness (Freeman 1977) and identify communities via the Louvain method (Blondel et al. 2008). The graphs were drawn with Gephi (Bastian, Heymann, and Jacomy 2009).

15 One could not have predicted this division by the mere legal existence of the DNA or DIICOT: the DNA itself was small and toothless for the first three years of its existence, as the prosecutor anti-corruption agency in neighbouring Bulgaria remains to this day. 


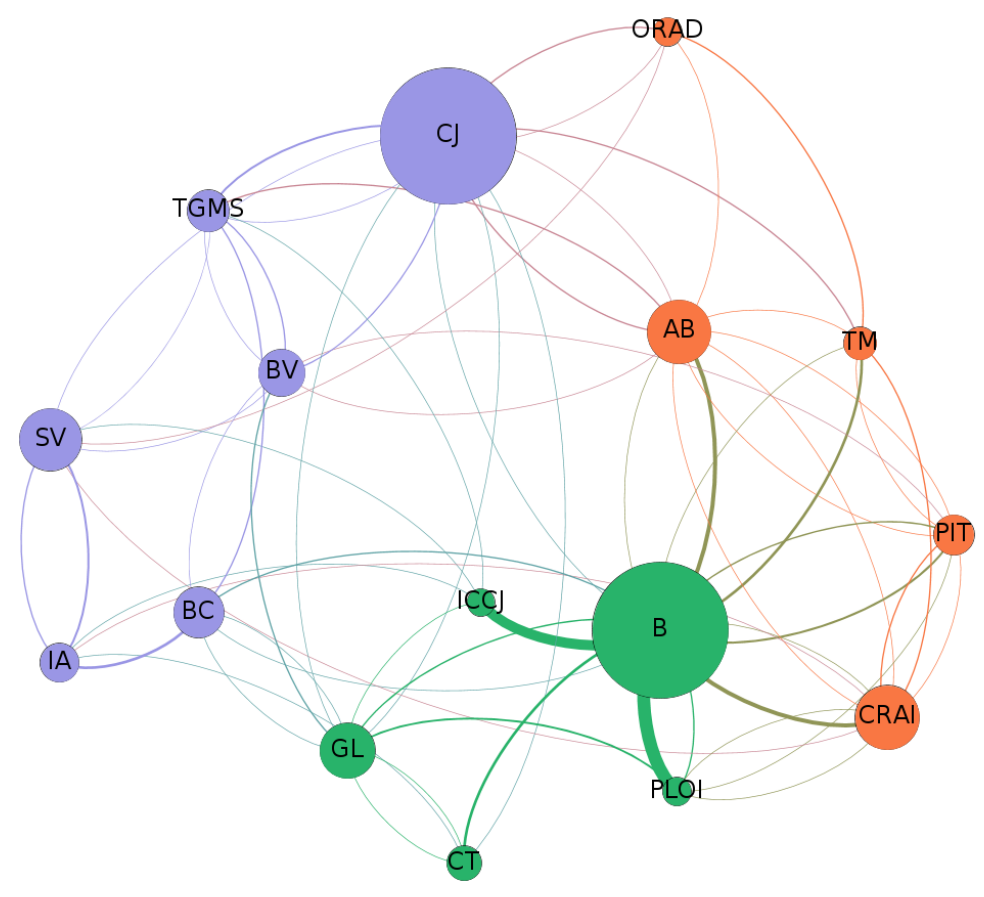

Figure 2: Inter-appellate region transfer network of judges, 2013. Colours indicate cliques/communities.

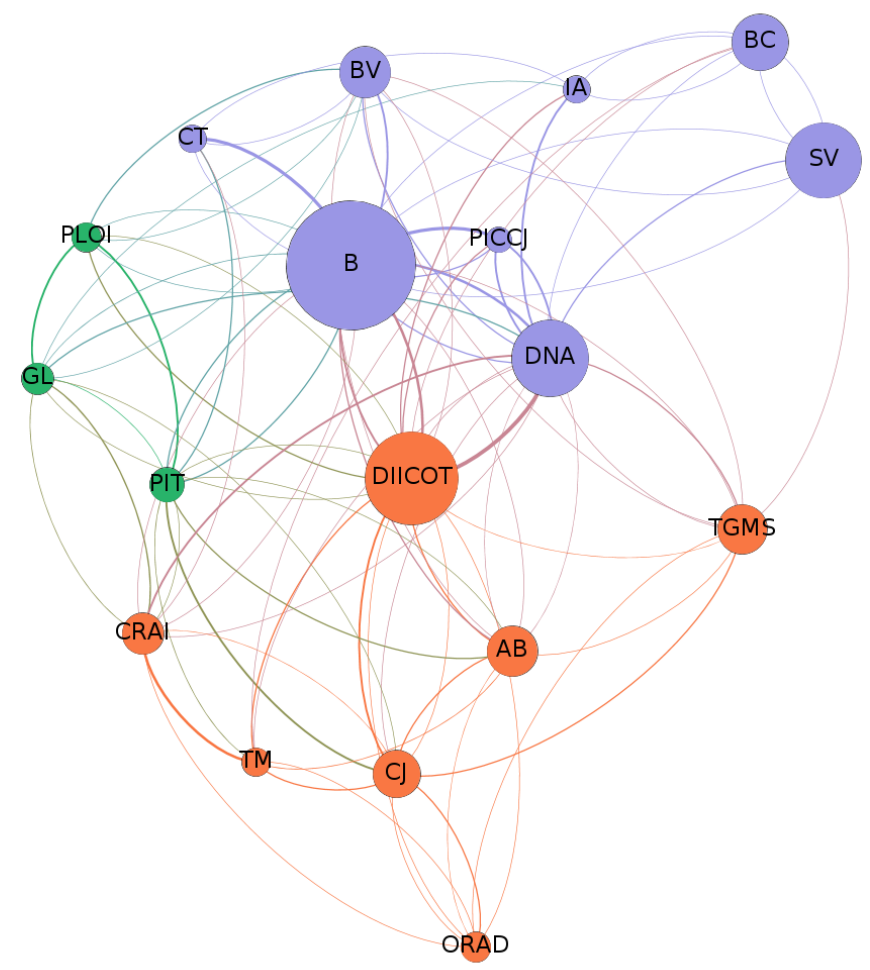

Figure 3: Inter-appellate region transfer network of prosecutors, 2013. Colours indicate cliques/communities. 
Percent Female and Membership Count for Romanian Legal Professions and Law School Graduate Cohorts, 1986-2018

Judges (1988-2018)

- sample -

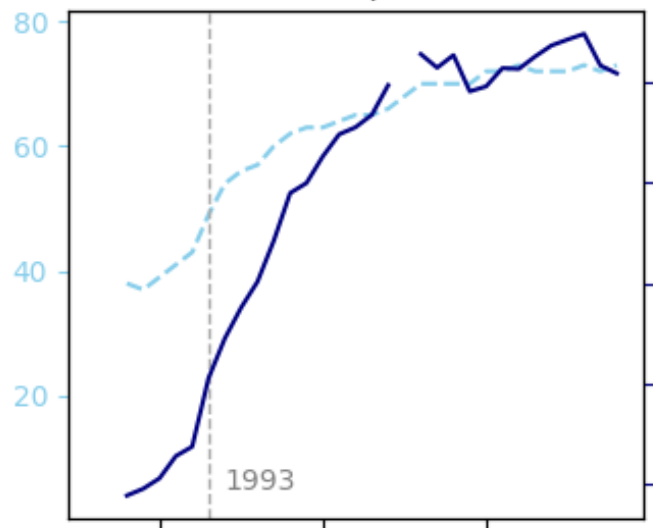

Notaries Public (1995-2018) - population -
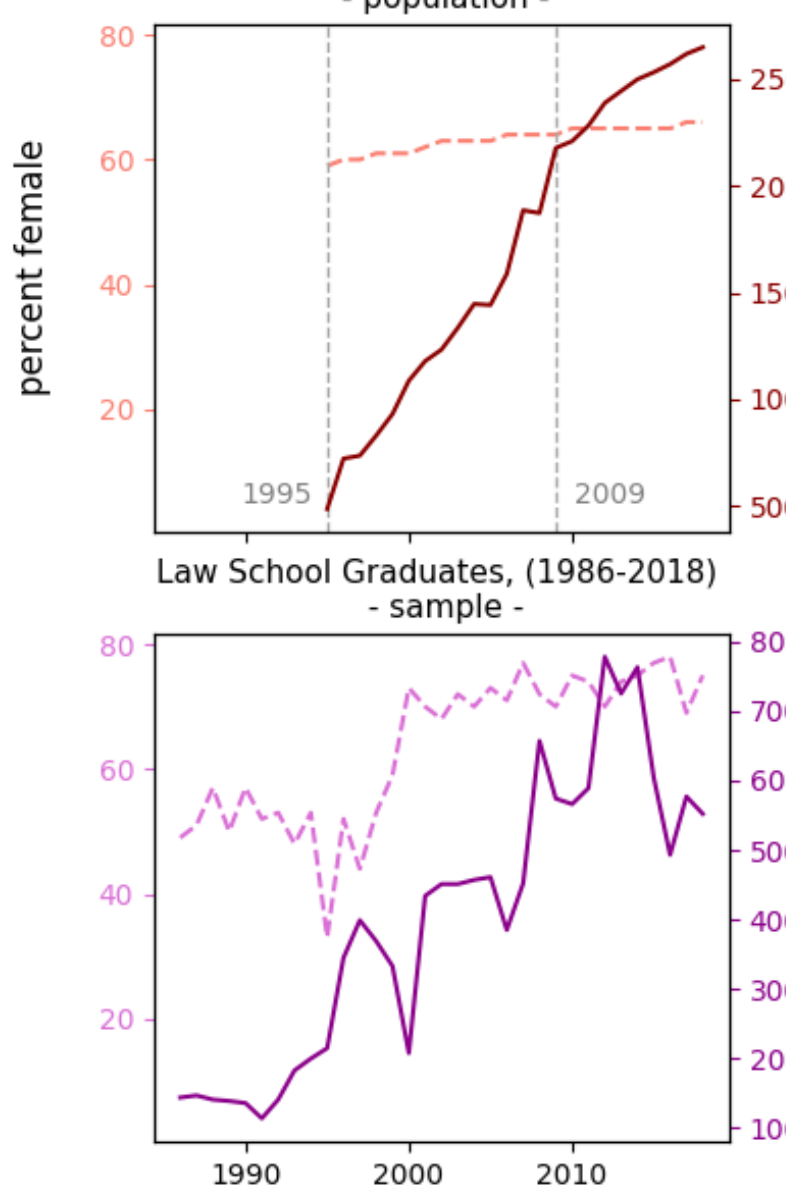

year
Prosecutors (1988-2018) - sample -

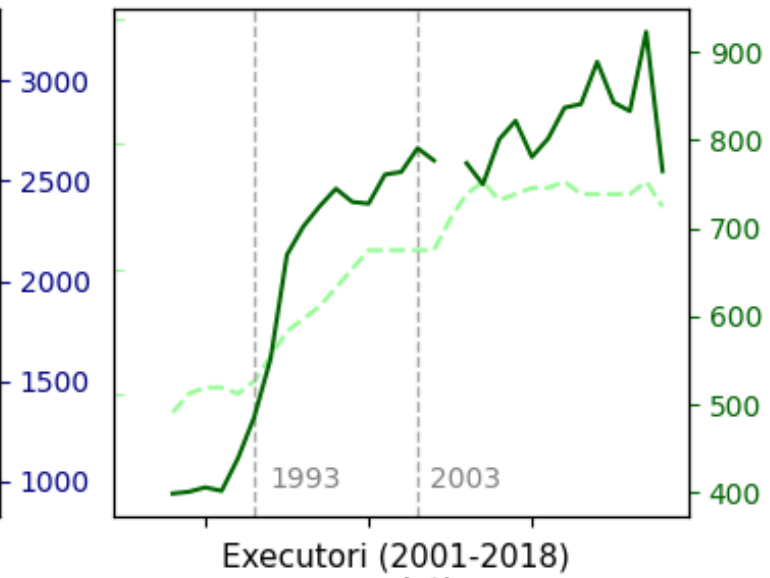

- population -

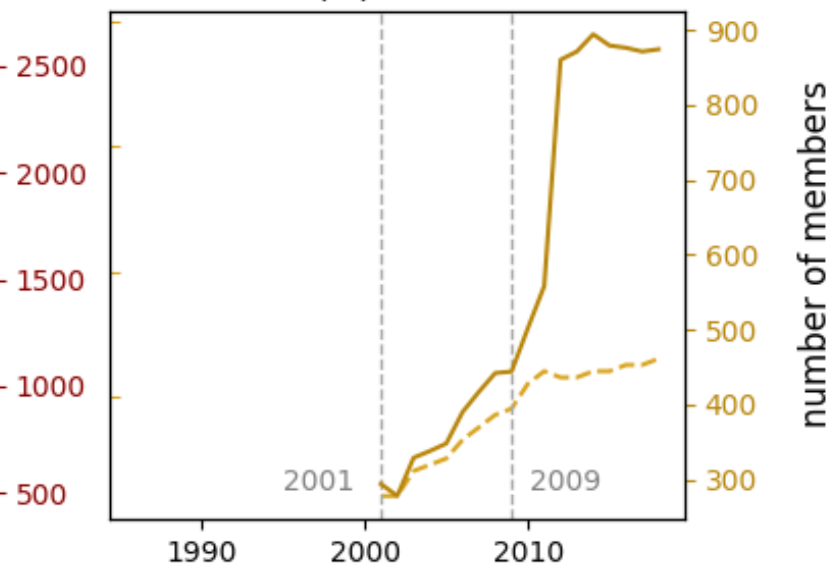

\section{- Number of Members}

--- Percent Female

Figure 4: Percent female and membership counts (sample or population) for Romanian legal professions and law school graduating cohorts, across various years 


\begin{tabular}{|c|c|c|c|c|}
\hline \multicolumn{5}{|c|}{$\begin{array}{l}\text { Conservative and Liberal Estimates of Professional Inheritance } \\
\text { for Notaries Public and Bailiffs (counts and percent of cohort) }\end{array}$} \\
\hline & & s Public & & liffs \\
\hline Year $\downarrow$ & Conservative & Liberal & Conservative & Liberal \\
\hline 1996 & $2(1 \%)$ & $12(5 \%)$ & \multirow{6}{*}{\multicolumn{2}{|c|}{ NA }} \\
\hline 1997 & $1(6 \%)$ & $2(11 \%)$ & & \\
\hline 1998 & 7 (7\%) & 13 (13\%) & & \\
\hline 1999 & $9(9 \%)$ & $16(16 \%)$ & & \\
\hline 2000 & 18 (11\%) & 41 (25\%) & & \\
\hline 2001 & $12(12 \%)$ & 21 (20\%) & & \\
\hline 2002 & 10 (16\%) & 21 (34\%) & $0(0 \%)$ & $0(0 \%)$ \\
\hline 2003 & 21 (19\%) & 30 (27\%) & $0(0 \%)$ & $0(0 \%)$ \\
\hline 2004 & 31 (26\%) & 54 (45\%) & $0(0 \%)$ & $0(0 \%)$ \\
\hline 2005 & $1(20 \%)$ & $2(40 \%)$ & $0(0 \%)$ & $0(0 \%)$ \\
\hline 2006 & 36 (23\%) & $63(40 \%)$ & $14(25 \%)$ & $14(25 \%)$ \\
\hline 2007 & 44 (14\%) & 86 (28\%) & $2(5 \%)$ & 7 (17\%) \\
\hline 2008 & $1(25 \%)$ & $1(25 \%)$ & $6(16 \%)$ & $9(24 \%)$ \\
\hline 2009 & 68 (22\%) & 122 (39\%) & $2(22 \%)$ & $2(22 \%)$ \\
\hline 2010 & 7 (17\%) & 12 (30\%) & $9(13 \%)$ & $11(16 \%)$ \\
\hline 2011 & 17 (20\%) & 32 (37\%) & 7 (11\%) & 12 (19\%) \\
\hline 2012 & 21 (16\%) & 42 (33\%) & $19(6 \%)$ & 29 (9\%) \\
\hline 2013 & 22 (28\%) & 37 (48\%) & $3(14 \%)$ & $4(19 \%)$ \\
\hline 2014 & 32 (44\%) & 42 (57\%) & 3 (7\%) & $5(12 \%)$ \\
\hline 2015 & 18 (28\%) & 32 (49\%) & $2(25 \%)$ & $4(50 \%)$ \\
\hline 2016 & $11(16 \%)$ & 20 (28\%) & $5(28 \%)$ & 6 (33\%) \\
\hline 2017 & $8(11 \%)$ & $14(19 \%)$ & $1(14 \%)$ & $1(14 \%)$ \\
\hline 2018 & $2(4 \%)$ & $11(20 \%)$ & $1(6 \%)$ & $2(12 \%)$ \\
\hline 2019 & $4(9 \%)$ & $13(28 \%)$ & $1(9 \%)$ & $2(18 \%)$ \\
\hline $\begin{array}{l}\text { Per Year Period } \\
\text { Average, percent }\end{array}$ & $16 \%$ & $28 \%$ & $9 \%$ & $14 \%$ \\
\hline
\end{tabular}

Table 10: Yearly (population-level) counts and percentages of inheritors of entry cohorts of notaries public (1996-2019) and bailiffs (2002-2019) 
As for socio-economic reproduction, Table 10 shows the yearly rates at which notaries public and bailiffs (executori judecătoreşti) inherit their professions. Averaged across at least fifteen years, every year between $16 \%$ and $28 \%$ of notaries, and $9 \%$ to $14 \%$ of bailiffs, obtain their profession by inheritance. ${ }^{16}$ Since a law degree is required to enter these professions it is clear that in Romania, like in most other countries, inheritance passes through a tertiary education system, whose costs are often justified on meritocratic grounds. Then again, a stable stratum of legal professionals supplies political, administrative, and civil society leaders in practically all liberal polities, including pre-communist Romania. If professional inheritance gives us a stable, non-oligarchic pool from which to recruit elites, the outcome might not be so bad.

\section{Conclusion}

I began this article by justifying the need for more data, especially regarding scholarship on the communist justice system, transitional justice, anti-corruption, and social stratification. I then introduced and described the Romanian Judicial Professions Database, a new, open-source database (composed of digital archives, the associated software package, and person-year tables) which features yearly, person-level data on 10,000 judges, 5300 prosecutors, 3000 notaries public (notari publici), and 1000 bailiffs (executori judecătoreşti). Finally I illustrated how this database can be used to address both long-standing expectations and open questions in studies of Romania.

Like most ambitious projects, the Romanian Judicial Professions Database is a work in progress. Three areas in particular require continued attention: expanding the coverage of the database, improving unique person identification, and devising better metrics for key concepts, like professional inheritance. Nonetheless, I hope to have convinced readers that this free, open-source database should be both used and improved.

In addition to piecemeal improvements, the next challenge is integrating the Romanian Judicial Professions Database with other publicly-available repositories, three of which are worth mentioning. First is the Romanian parliamentary database, available on the websites of the Romanian Senate and Chamber of Deputies. It would be particularly interesting to see how magistrates are mentioned in parliamentary speeches, and to ascertain the degree to which the legislative process (e.g. the path of judicial reform bills) affects magistrate careers. Another option is integrating the current database with media archives: Ziare.com, Hotnews.ro, and Revista22 all have free, digital archives. Again, a key focus would be the representation of Romanian legal professionals.

Most promising, however, is to link the Romanian Judicial Professions Database with actual court data, which is publicly available from Romania's e-justice website, https://portal.just.ro. In this way we could finally address the heart of the matter: which judgements are passed, and why? It is

16 I estimate professional inheritance by seeing whether the surname of a new recruit in Year X matches the surname of a legal professional that is already practising in the same chamber (cameră); chambers correspond to multi-county appellate court jurisdictions. This is a rough proxy with high face value: two professionals with the same surname in the same area are probably kin. The conservative estimate only considers those professionals whose surname appears at most three times in the entire profession: this makes it unlikely that unrelated people with common surnames will be coded as kin. The liberal coding scheme ignores only the top three most common surnames, typically variants of "Pop." Additional conditions are applied to Bucharest, because of its great size. 
therefore my hope that these new tools at our disposal, including the Romanian Judicial Professions Database, will usher in a new wave of research on justice in Romania.

\section{Works Cited}

Andrén, Daniela, John S. Earle, and Dana Săpătoru. 2005. "The Wage Effects of Schooling under Socialism and in Transition: Evidence from Romania, 1950-2000." Journal of Comparative Economics 33(2):300-323.

Bastian, Mathieu, Sebastien Heymann, and Mathieu Jacomy. 2009. "Gephi: An Open Source Software for Exploring and Manipulating Networks." International AAAl Conference on Weblogs and Social Media.

Blondel, Vincent D., Jean-Loup Guillaume, Renaud Lambiotte, and Etienne Lefebvre. 2008. "Fast Unfolding of Communities in Large Networks." Journal of Statistical Mechanics: Theory and Experiment 2008(10):P10008.

Crăcană, luliu. 2015. Dreptul în slujba puterii: justiția în regimul comunist din România, 1944-1958. Institutul Național pentru Studiul Totalitarismului.

Curseu, P. L., and S. Boros. 2008. "Stereotypes and Prejudice towards Women Managers." Studia Psychologica 50(3):233.

Digi24. 2019. "Guvernul a aprobat modificarea Legilor Justiției prin ordonanță de urgență." Digi24, February 19.

Dorondel, Ștefan. 2016. Disrupted Landscapes: State, Peasants and the Politics of Land in Postsocialist Romania. New York: Berghahn Books.

Dragoman, Dragoș. 2020. “'Save Romania' Union and the Persistent Populism in Romania." Problems of Post-Communism 1-12.

Freeman, Linton C. 1977. "A Set of Measures of Centrality Based on Betweenness." Sociometry 40(1):35-41.

Gherghina, Sergiu, and Sorina Soare. 2017. "From TV to Parliament: The Successful Birth and Progressive Death of a Personal Party: The Case of the People's Party Dan Diaconescu." Politologicky Casopis 24(2).

Kligman, Gail, and Katherine Verdery. 2011. Peasants under Siege: The Collectivization of Romanian Agriculture, 1949-1962. Princeton University Press.

Mihăescu, Alexandru. 2018. "Detalii despre adevăratul stat paralel creat de PSD: Rodica Stănoiu a numit conducerea SIPA la cererea șefului SRI din acea perioadă, Radu Timofte." G4Media.ro, June 13.

Pârvulescu, Radu Andrei. 2020a. "COVID19 and Judicial Appointments." in European Consortium for Political Research Virtual General Conference. Online. Preprint at:

https://osf.io/preprints/socarxiv/hg9tq 
Pârvulescu, Radu Andrei. 2020b. "Engineering Your Judiciary, or How the COVID Crisis Won't Go to Waste." Discover Society, April 24. url: https://discoversociety.org/2020/04/24/engineeringyour-judiciary-or-how-the-covid-crisis-wont-go-to-waste/

Protsyk, Oleh, and Marius Lupsa Matichescu. 2011. "Clientelism and Political Recruitment in Democratic Transition: Evidence from Romania." Comparative Politics 43(2):207-24.

Ridgeway, Cecilia L. 2011. Framed by Gender: How Gender Inequality Persists in the Modern World. Oxford University Press.

Stan, Lavinia, and Marian Zulean. 2018. "Intelligence Sector Reforms in Romania: A Scorecard." Surveillance \& Society 16(3):298-313.

Stoica, Cătălin Augustin. 2004. "From Good Communists to Even Better Capitalists? Entrepreneurial Pathways in Post-Socialist Romania." East European Politics and Societies 18(2):236-277.

Tismaneanu, Vladimir. 2003. Stalinism for All Seasons: A Political History of Romanian Communism. University of California Press.

Tomescu-Dubrow, Irina. 2006. "Intergenerational Social Mobility in Romania: Changes in the Patterns of Flows and Relationships in the Postcommunist Era." International Journal of Sociology 36(1):46-68.

Voicu, M?lina, and Paula Andreea Tufiş. 2012. "Trends in Gender Beliefs in Romania: 1993-2008." Current Sociology 60(1):61-80.

\section{Appendix A: Attributes/Variables by Group}

Judges: row ID, unique person ID, surnames, given names, sex/gender, workplace, year, appeals area code, tribunal code, low court code, judicial level.

Prosecutors: row ID, unique person ID, surnames, given names, sex/gender, workplace, year, appeals area code, tribunal code, low court code, judicial level.

Notaries Public (notari publici): row ID, unique person ID, surnames, given names, sex/gender, year, chamber, town, inheritor status.

Bailiffs (executori judecătorești): row ID, unique person ID, surnames, given names, sex/gender, office address, year, chamber, town, apprenticeship (stagiu), inheritor status, other information

Law School Graduates: unique ID, sex/gender, year of graduation 